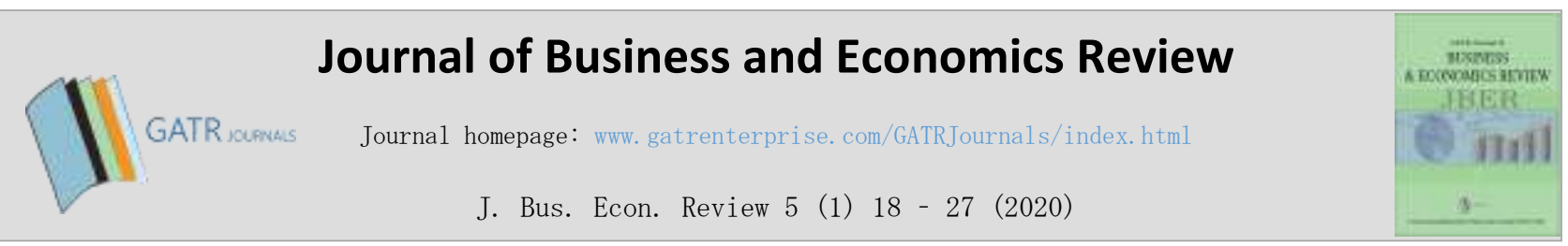

\title{
Assessing the Attitudes, Aspirations, and Gender Differences of Pre - service Mathematics Teachers
}

\author{
Renalyn P. Mora ${ }^{1}$ \\ Isabela State University, San Andres, San Mateo, Isabela, 3318, Philippines
}

\begin{abstract}
Objective - This study was conducted to assess the attitudes, aspirations and gender differences of pre - service Mathematics teachers of Isabela State University for the 2nd semester of school year 2018 - 2019. Developing students' attitudes and aspirations through highlighting the gender difference and relevance of mathematics to everyday life maybe beneficial.

Methodology/Technique - This study has a total number of 106 participants of which 72 are females and 34 are males. A quantitative descriptive research design was employed in this study with four - part questionnaire which included the students' profile, attitude, aspiration, and motivation as the data gathering instrument. The data was tabulated, analyzed and interpreted according to the objectives of the study. A Z - test was used to analyze and determine the significant difference between gender and attitude as well as for, motivation, and aspiration.

Findings - Based on the findings of the study, it is concluded that gender affects the attitude of the pre - service Mathematics teachers in learning Mathematics as well as their aspirations. Finally, it was also recommended to do further research to this topic in other disciplines to reduce skill disparities among students.
\end{abstract}

Type of Paper: Empirical.

Keywords: Attitudes; Aspirations; Motivation; Gender Differences; Gender.

Reference to this paper should be made as follows: Mora, R.P, (2020). Assessing the Attitudes, Aspirations, and Gender Differences of Pre - service Mathematics Teachers, J. Bus. Econ. Review, 5(1) 18-27. https://doi.org/10.35609/jber.2020.5.1(3)

JEL Classification: A29, M14, M19.

\section{Introduction}

Development is a process of the amendment that includes various fundamental changes in social structure, attitudes of citizens, national institutions, economic growth, and all aspects of state life (Todaro \& Smith, 2017). Poverty is still the biggest obstacle to the development process because of the inability of the population to obtain sufficient income to meet their daily needs. One way the government can address this problem is to implement sustainable development (United Nations (UN) Sustainable Development Goals (SDGs) program, which has 17 goals and 169 targets (Suresh \& Johnson, 2015)). At SDGs, all objectives were interconnected, so success at one goal will solve problems at another (UNDP, 2016).

\footnotetext{
*Paper Info: Revised: January 11, 2020

Accepted: March 30, 2020

* Corresponding author: Renalyn P. Mora

E-mail: renalyn.mora@isu.edu.ph

Affiliation: Isabela State University, San Andres, San Mateo, Isabela, 3318, Philippines
} 
Gender differences have been an issue for a long time. Gender bias and inequality is still prevalent in our world, where legal, political, institutional and economic processes work against it. It is a common place to see gender stereotypes manifested in day to day life (Arigbabu \& Mji, 2004)

Accordingly, gender difference and gender bias in terms of performance in mathematics is very dominant in the workplace and in different institution due to the belief that males are better in math than females. Men have better access to policy making positions, political leadership and other seats of power. Females are meant to take care of the family and household chores which do not require higher educational achievements. However, from generation to generation, developments and advancement have brought opportunities to both genders and females are now performing just as well as males in mathematics (Cheryan, 2011) since opportunities have been available and open to take.

The depth of mathematical knowledge an individual has dictates the level of accuracy in decision making. Consequently, regardless of gender, one must be good in mathematics as it implies that before an individual can function well in society, one must possess relatively good knowledge of mathematics especially in this technological age. With this notion, educators are consistent in providing a variety of strategies to attain the goal of the community which is to develop a holistic individual which in turn will result in a sustainable society. Specifically, Mathematics teachers exert countless efforts to provide quality education to their students, however, it was observed that negative attitudes towards mathematics is reflected in their poor performance, which influences the students' decision to take mathematics related courses.

Gender differences are a recurrent theme throughout the literature in academic studies in general and in math studies in particular. Math is often considered to be a domain in which boys are higher achievers as different factors can affect learning and academic achievements. For this reason, the objective of this paper is to discuss whether the mathematical teaching skills of males and females differ as well as their attitudes, aspirations, and motivational factors.

\section{Literature Review}

\subsection{Gender Differences}

According to Barmao (2006), a majority of girls perceive information concretely and process it reflectively. They learn best by personal involvement, listening and sharing ideas. Boys on the other hand perceive information abstractive and process it actively. They learn best through hands - on activities and self - discovery. How much gender role is influenced by biology and how much by environment is still a matter of conjecture but is evident that both influences are involved. With new information about cognitive differences, girls should know that there are many reasons why they can do well in mathematics and science.

Different information processing styles of students may account for gender difference. Teachers need to be cognizant of these differences and understand that not only do children learn differently but good students may learn from the way a teacher delivers the subject content. If a child approaches a learning task in a way that is different from the way the teacher would, it does not necessarily make either approach better or worse than the other. Using this information will help all the students. However, there are two sides to the academic arguments about cognitive gender differences. One group works at research on adults and concludes that, because men and women don't differ a great deal on cognitive measures, the education of children should focus on similarities that exist between boys and girls.

Generally, this group believes that if gendered educational principles are used, the difference between boys and girls will widen. The other group concludes that the problems that girls have with mathematics and science that boys have with language and arts begin early and only by using gendered educational approaches will men and women become more equal in their cognitive abilities (Norfleet, 2007). Hence, this research 
aims to identify the effect of students' cognitive development and mathematical abilities on mathematics performance.

\subsection{Attitudes}

It is generally believed that human beings are social persons with beliefs, emotions and views which does not only influence but also determine their choices. Teachers' belief about mathematics plays a major role in shaping their instructional practice, and consequently influences their pupils' attitudes, interests and achievement (Nicolaidou \& Philippou, 2003).

Mathematics teachers' styles of teaching depends on their systems of beliefs, in particular, on their conception of the nature of mathematics, and on their mental models of teaching and learning mathematics. Teachers' attitudes towards the nature of mathematics are likely to affect students' performance in mathematics.

\subsection{Aspirations}

According to the Longman Advanced American Dictionary, to qualify is to have the right to do something. Thus a qualified mathematics teacher is one who has the right to teach mathematics. Although this right complies with the respective educational policies of each nation, there are two main and common components of the issue. These include the teacher's knowledge of the content, and the possession of appropriate teaching skills. More practically, this can be stated that a qualified mathematics teacher is one who is majored or minored in mathematics.

In general, researchers have found that possessing a major or minor in mathematics or science is related to increased student achievement in these subject areas. Students taught by teachers with degrees in mathematics had greater gains in achievement than students taught by teachers with non - mathematics degrees (Alexander \& Fuller, 2005).

Few educators, economists, or politicians would argue with the contention that, all other things being equal, highly qualified teachers produce greater students' achievement than comparatively less qualified teachers. Indeed, good teachers have distinguishable impacts on student exam scores (Alexander \& Fuller, 2005). On the other hand, having a qualified mathematics teacher in the classroom is a problem almost everywhere.

Despite the fact that research findings strongly emphasize the importance of having qualified mathematics teachers in the classroom, there is an acute shortage of qualified mathematics teachers in most parts of both the developed and the developing countries. According to Bob (2007), in all parts of the world, attracting young or mature entrants into teaching is a major challenge. In Europe, the United States, in South and West Asia, and Africa, problems to recruit competent teachers still exist. In many countries and regions, recruitment to specialist subject areas is particularly problematic especially in mathematics and science. He also points out that the age profile of the teaching profession is also problematic with large percentages of teachers likely to retire in the coming decade. Many education systems are supplementing teachers with a growing cadre or para - professionals playing a variety of roles. His study also revealed that teachers are dissatisfied with the salary scales and lack of promotion in teaching services. Therefore, there was a need for this research.

Career development theories were originally based on white males from middle and middle-upper class backgrounds (Coogan \& Chen, 2007). Richardson and Watt (2005 \& 2006) posit that gender differences between men and women in the teaching profession are an issue. "In Australia, women make up two thirds of all teachers..." Demographic data show that when the number of females entering a profession increases, the number of males decreases (Jacobson \& Moore, 2005). The number of men entering the profession is 
decreasing in the US, Canada, and Australia. Teaching has been feminized during the last century. Consequently, it becomes very difficult for post-secondary institutions to recruit male students for teaching careers, especially for elementary schools. Then the chain effect unravels, preventing schools' principals from having a gender balanced teacher faculty, especially where male role models are highly needed.

George (2006) identifies a huge disparity between the number of male $(6 \%)$ and female $(94 \%)$ pre service teachers. Aud et al. (2011) reported that in 2007 - 2008 the majority of full-time teachers were female. Males might perceive a female dominated occupation as an economically undesirable and uncomfortable fit with their gender identity (Jacobson \& Moore, 2005). In 2011, female full-time workers made only 77 cents for every dollar earned by men, producing a gender gap of $23 \%$ (Institute for Women's Policy Research, 2010).

\subsection{Motivational Factors}

In order to determine why college - aged students think the way they do, it would behoove one to start at the very beginning of the post - college thought process. This thought process actually begins as early as elementary school, when children are first dreaming and discovering what motivates and inspires them in their lives. Auger, Blackjurst and Wahl (2005) conducted a study to determine: first, at what point in a child's life in their future aspirations became specific and realistic enough to be taken seriously, and second, if these aspirations had any correlation to their parents' career fields. While it was predicted by most that fantasy and realistic career answers would be given by younger children, it was actually the older children who mentioned careers fitting into this category.

Of the 1st, 3rd, and 5th graders who were tested, half of them could not specifically define one or both of their parents' occupations when prompted. Of the ones who knew, only $6 \%$ and $10 \%$ answered that they wanted to grow up to be just like Mommy and Daddy, respectively. There was "little correspondence between parents' jobs and the jobs children stated they wanted to have" (Auger, Blackjurst \& Wahl, 2005). These numbers show that young children, who are socially accepted to be at an age that idolizes their parents, actually do not seem to pay much attention when it comes to their parents' field of work. As a result, the question that arises is: At what age do children begin to ask about their parents' careers, and where does the motivation and inspiration to eventually follow in their footsteps come from?

Kniveton (2004) narrowed down in his study that the top three motivating factors behind choosing a career for participants These are:

1. they enjoyed the work;

2. the amount of salary that was paid; and

3. that it was something they were "good" at.

In a different study done specifically on teacher development, 79 pre-service teachers indicated that their own three key motivators influencing their decision to choose teaching were:

1. personal fulfilment;

2. enjoyment of the subject; and

3. the opportunity to work with young people (Manuel \& Hughes, 2006).

With these motivators in mind, it makes it clearer on just what direction children are eventually led to in decision - making.

More recently, Eren (2012) conducted research in Turkey questioning 602 pre-service teachers aged 17 39 years old to determine how an individual's interest in teaching was explicitly related to their career choice 
satisfaction beliefs. In the study, teaching was explicitly related to their career choice satisfaction beliefs. In that study, participants were profiled as high, medium, and low interest levels in teaching based on their survey responses. It was concluded that being rated with a high interest in the subject matter they were teaching directly correlated to higher satisfaction rates with their career choices. These choices pave the way to promoting what motivates people to join fields of interest and what keeps them passionate once they are settled in their careers (Johnson, 1996).

These things that keep teachers passionate could be the reasons for starting their degrees in the first place. Manuel and Hughes (2006) asked 79 teachers if teaching was their original choice of career, to which just over half answered 'yes'. Of those that answered 'yes' $14 \%$ admitted to having a family history of teachers, a reason that might otherwise influence their decision. $73 \%$ of all participants stated that a significant mentor in their life which included parents or counsellors had a direct impact on their decision to teach. This research suggests that family member, as well as others, have a huge influence and serve as a potential motivating factor for pre-service teachers choosing the teaching profession.

\section{Research Methodology}

This study involves the use of a quantitative descriptive survey method. A well developed and constructed questionnaire was utilized by the researcher with the aim of collecting information on attitudes, aspirations, and motivations.

\subsection{Data Gathering Instrument}

To address the purpose of this study, the data were collected using a four-part questionnaire:

a) General information of the respondent;

b) Mathematics Attitude Survey;

c) Career Choice; and

d) Motivational Factors in choosing the Teaching Career.

General information includes the following: (1) ISU Campus where the student is currently studying, and (2) sex of the respondent. For the attitude, career choice and motivational factors, all responses are given on a 5-point Likert type scale (from 1 - Strongly Disagree to 5 - Strongly Agree). The Mathematics Attitude Survey comprised of 30 items distributed over three aspects: Confidence in learning, Awareness in the importance of mathematics and Engagement in studying mathematics. The 24 items under Career Choice are spread across four dimensions: intellectual, social, ethical, and professional. The Motivational Factors in choosing the teaching career consisted of 29 items distributed across intrinsic, altruistic and extrinsic dimensions.

The adequacy of item inclusion in the attitude, career choice and motivational dimensions were verified, and the reliability has been analyzed using Cronbach's Alpha. The reliability scores can be considered adequate as the Cronbach's Alpha coefficients are 0.91 for the Mathematics Attitude Survey, 0.90 for the Career Choice, and 0.89 for Motivational Factors.

\section{Results and Discussion}

The results of this study are presented through descriptive statistics of the respondents' attitudes in learning mathematics, aspiration and motivational factors in choosing the teaching career. The differences of the respondents are in relation to their gender. 


\subsection{Attitude in Learning Mathematics}

The attitudes considered in this study are confidence, awareness of the importance of mathematics and engagement while learning mathematics.

Table 1. Attitude of Pre-service Mathematics Teachers

\begin{tabular}{|c|c|c|c|c|c|}
\hline \multirow{2}{*}{ Aspect of Attitude } & \multicolumn{2}{|c|}{ Female } & \multicolumn{2}{|c|}{ Male } & \multirow{2}{*}{ Computed Z Value } \\
\hline & Mean & Description & Mean & Description & \\
\hline Confidence & 3.35 & $\begin{array}{c}\text { Moderately } \\
\text { Favorable }\end{array}$ & 3.53 & Favorable & $-2.1158^{s}$ \\
\hline $\begin{array}{l}\text { Mathematical } \\
\text { thinking }\end{array}$ & 3.56 & Favorable & 3.87 & Favorable & $-3.901^{s}$ \\
\hline $\begin{array}{l}\text { Comfortable in } \\
\text { Learning } \\
\text { Mathematics }\end{array}$ & 2.65 & $\begin{array}{l}\text { Moderately } \\
\text { Favorable }\end{array}$ & 2.51 & $\begin{array}{l}\text { Moderately } \\
\text { Favorable }\end{array}$ & $1.5777^{n s}$ \\
\hline Awareness & 2.68 & $\begin{array}{l}\text { Moderately } \\
\text { Favorable }\end{array}$ & 2.86 & $\begin{array}{l}\text { Moderately } \\
\text { Favorable }\end{array}$ & $2.32^{s}$ \\
\hline Engagement & 3.18 & $\begin{array}{c}\text { Moderately } \\
\text { Favorable }\end{array}$ & 3.30 & $\begin{array}{l}\text { Moderately } \\
\text { Favorable }\end{array}$ & $-1.538^{n s}$ \\
\hline Prefer & 3.49 & $\begin{array}{l}\text { Moderately } \\
\text { Favorable }\end{array}$ & 3.54 & Favorable & $-0.415^{n s}$ \\
\hline Enjoyment & 2.63 & $\begin{array}{l}\text { Moderately } \\
\text { Favorable }\end{array}$ & 2.72 & $\begin{array}{l}\text { Moderately } \\
\text { Favorable }\end{array}$ & $-1.092^{n s}$ \\
\hline $\begin{array}{l}\text { Overall mean } \\
\text { rating }\end{array}$ & 3.09 & $\begin{array}{c}\text { Moderately } \\
\text { Favorable }\end{array}$ & 3.25 & $\begin{array}{c}\text { Moderately } \\
\text { Favorable }\end{array}$ & $-2.254^{s}$ \\
\hline \multicolumn{6}{|c|}{$\mathrm{s}$ - significant at .05 level of significance (two - tailed) } \\
\hline
\end{tabular}

Table 1 shows the three aspects of attitude towards learning mathematics and reveals that in terms of confidence, males have a higher mean rating; (3.53) which reveals a favorable attitude than females with 3.56, marked as moderately favorable. Moreover, the computed $\mathrm{z}$ value is -2.1158 which fall under the rejected region with $\mathrm{z}$ critical two-tailed value of \pm 1.96 . Hence, there is a significant difference between the attitudes of male and female respondents in terms of confidence. This means that males are more confident in learning mathematics than females. This is consistent with the results of the study of Ismail and Halima (2007) which states that boys portray higher self-confidence levels as perceived. They seemed to think that they tend to do well in mathematics and that they understand quickly in learning the subject.

Despite males being confident in learning mathematics, both genders are comfortable in learning the subject, and both gained favorable responses. The computed $\mathrm{z}$ value is 1.5777 which fall under the accepted region still with $\mathrm{z}$ critical two tailed value of \pm 1.96 . This conveys that there is no significant difference in terms of being comfortable in learning mathematics according to gender. Gender is not a basis of being comfortable in learning mathematics. 
Attitude towards awareness of the application of mathematics of the respondents was also revealed in this table. Comparing both means, 2.86 and 2.68 for male and female respectively, both of which are moderately favorable, with a $\mathrm{z}$ value of -2.32 which falls under the rejected region with $\mathrm{z}$ critical two-tailed value of \pm 1.96 . This means that there is a significant difference between the awareness of both genders. Male preservice mathematics teachers perceive the importance of mathematics in everyday life and in other fields of study more than females do.

As the saying by Benjamin Franklin goes "Tell me and I forget, teach me and I remember, involve me and I learn", engagement while learning is one of the aspects of attitude. With the means of 3.30 and 3.18 for both males and females respectively, both of which are moderate favorable, males have a higher mean towards engagement but this does not mean that there is a significant difference between means, since the computed $\mathrm{z}$ value is -1.538 which fall under the accepted region. Both genders have positive attitudes toward engagement while learning. Both male and females agree that better learning will occur if engagement is integrated inside the classroom.

Generally, there is a significant difference between the means of 3.25 and 3.09 for both males and females respectively in terms of attitudes in learning mathematics but both are considered as moderately favorable. However, the computed $\mathrm{z}$ value is -2.254 , which falls under the rejected region of the null, with critical value \pm 1.96 . In other words, males tend to have a better and more positive attitude towards learning mathematics than females. This is in contrast with the results of the study by Ali et. al. (2016) which concludes that gender differences have no impact on the attitude of students towards mathematics. This presence of contradiction may be affected by the locality and place of study together with the culture present in that area.

\subsection{Career Choice}

The career choice of the pre-service mathematics teachers are expounded in four dimensions - intellectual, social, ethical and professional. In these dimensions, the males have higher mean ratings compared to the females.

Table 2. Aspirations of the Pre-service Mathematics Teachers

\begin{tabular}{|c|c|c|c|c|c|}
\hline \multirow{2}{*}{ Dimensions of Career Choice } & \multicolumn{2}{|c|}{ Female } & \multicolumn{2}{c|}{ Male } & Computed \\
\cline { 2 - 7 } & Mean & Description & Mean & Description & Zalue \\
\hline Intellectual & 4.58 & Very High & 4.73 & Very High & $-1.537^{n s}$ \\
\hline Social & 4.36 & High & 4.62 & Very High & $-2.56^{s}$ \\
\hline Ethical & 4.56 & Very High & 4.73 & Very High & $-2.023^{s}$ \\
\hline Professional & 4.49 & High & 4.69 & Very High & $-1.91^{n s}$ \\
\hline Overall mean rating & $\mathbf{4 . 5 3}$ & Very High & $\mathbf{4 . 7 1}$ & Very High & $-2.097^{s}$ \\
\hline \multicolumn{7}{r}{ s - significant at .05 level of significance (two - tailed) } \\
\hline
\end{tabular}

There are four dimensions under career choice: intellectual, social, ethical and professional as identified in this study. In terms of intellectual and professional with means 4.73 and 4.58 under intellectual and 4.69 and 4.49 under professional for both males and females respectively. Intellectual dimension was regarded as very high which signifies that the pre-service mathematics teachers look up to teaching career as an avenue to attain high intellectual ability. The same is true with professional dimension with high and very high as remark made by female and males' respondents respectively. 
The pre-service mathematics teachers aspire to be in the teaching profession since it offers professional growth. Males have a higher value for mean but not high enough to say that there is significant difference between the means since the computed $\mathrm{z}$ value is-1.537 for intellectual and -1.91 for professional, which both fall under the accepted region. This shows that both genders aspire to be in the teaching profession since both know the growth it can offer to intellectual and professional dimensions of life. Gender does not affect the choice made by pre-service mathematics teachers.

Furthermore, in terms of social and ethical dimensions with means 4.62 and 4.36 under social dimension which marked as high and very high respectively and 4.69 and 4.49 under ethical which marked as very high for both means. However, both $\mathrm{z}$ values for social and ethical are -2.56 and -2.023 respectively, which fall under the rejected region. Pre-service mathematics teachers perceive that being in the teaching profession their social and ethical dimensions of life will be developed. In addition, in this case gender affects the choice made by the pre-service mathematics teachers.

Generally, with the value of mean of 4.17 and 4.53 for males and females respectively, regarded as very high, there is enough evidence to reject the null since, the computed $\mathrm{z}$ value is -2.097 under the critical value 土1.96. This signifies that males tend to choose the teaching profession. That is, they aspire to become teachers mainly because of the knowledge and skills they want to share to students. In addition, they want to give advice and guidance to students to make the right choices in life. Ethically, teachers for them are role models of the youth. Their aspiration is to develop students holistically with confidence and competence in life, with sense of order, discipline and leadership. Thus, gender plays a vital role in choosing a career.

\subsection{Motivational Factors}

The motivation for the teaching profession considered in this study is divided into three aspects - intrinsic, altruistic and extrinsic.

Table 3. Motivational Factors of the Pre-service Mathematics Teachers

\begin{tabular}{|c|c|c|c|c|c|}
\hline \multirow{2}{*}{ Motivational Factor } & \multicolumn{2}{|c|}{ Female } & \multicolumn{2}{|c|}{ Male } & \multirow{2}{*}{$\begin{array}{c}\text { Computed Z } \\
\text { Value }\end{array}$} \\
\hline & Mean & Description & Mean & Description & \\
\hline Intrinsic & 4.45 & High & 4.42 & High & $0.6422^{n s}$ \\
\hline Intellectual stimulation & 4.42 & High & 4.38 & High & $0.6551^{n s}$ \\
\hline Personal and Professional growth & 4.56 & Very High & 4.56 & Very High & $0.3804^{n s}$ \\
\hline Altruistic & 4.26 & High & 4.19 & High & $0.8812^{n s}$ \\
\hline Interpersonal relationship & 4.31 & High & 4.38 & High & $-0.82^{n s}$ \\
\hline Service to the society & 4.21 & High & 4.0 & High & $2.1557^{s}$ \\
\hline Extrinsic & 3.73 & High & 3.71 & High & $0.3646^{n s}$ \\
\hline $\begin{array}{l}\text { Job security and good working } \\
\text { condition }\end{array}$ & 3.70 & High & 3.75 & High & $-0.357^{n s}$ \\
\hline Material and free time benefits & 3.55 & High & 3.5 & High & $0.4496^{n s}$ \\
\hline Improve social standing & 4.08 & High & 4.02 & High & $0.565^{n s}$ \\
\hline Overall mean rating & 4.13 & High & 4.09 & High & $0.7674^{n s}$ \\
\hline $\begin{array}{r}\mathrm{s}-\text { sign } \\
\text { ns - not si }\end{array}$ & at .0 & of signif & two & & \\
\hline
\end{tabular}


There are several motivational factors in terms of choosing the teaching profession, in this study, the researcher identified three of those: Intrinsic, Altruistic and Extrinsic factors.

The female pre-service mathematics teachers are more intrinsically motivated than males, with mean of 4.45 and 4.42, respectively which both regarded as high. However, this result is not significant enough to say that there is difference between these two means since the computed $\mathrm{z}$ value is 0.6422 which falls within the accepted region with a $\mathrm{z}$ critical value of \pm 1.96 . This reveals that both genders are intrinsically motivated. This result is consistent with the study of Azman (2012) in Malaysia which concludes that both males and females are altruistic and intrinsic.

The same is true with intrinsic; both males and females are altruistically motivated and regard it as high. Moreover, there is no significant difference between their means since the computed $\mathrm{z}$ value is 0.8812 . However, in terms of service to the society, females are more motivated to choose teaching as a career. That is, female regards to teaching as an avenue to serve the society as a responsible citizens of the nation.

On the other hand, both genders are extrinsically motivated and fall under the category high. Moreover, there is no significant difference in terms of means with a computed $\mathrm{z}$ value of 0.3646 . Yet, this motivational factor ranks last among the three. These results are similar to the findings of Azman (2012) who states that the choice of the pre-service mathematics teachers is not affected by external factors or extrinsic motivation. Despite this, extrinsic motivation involves "good salary", "benefits" and other considerations.

Overall, pre-service mathematics teachers are highly motivated to choose teaching as a profession. Furthermore, there is not enough evidence to say that there is significant difference since the computed $\mathrm{z}$ value is 0.7674 which falls under the accepted region of the null. This indicates that, whether intrinsically, altruistically and extrinsically, pre-service mathematics teachers are motivated and positive to become teachers regardless of the benefits it offers and convenience it provides. Thus, gender does not affect the motivation a person has. It has nothing to do with the choice a person will make.

\section{Conclusion}

Gender differences among pre-service mathematics teachers are significant in some respects. From the analysis and interpretation described in the study, the results reveal that the number of male pre-service teachers is much lower than the number of female pre-service teachers. This indicates that only a few males consider and continue pursuing mathematics education. This displays a need to attract more competent male students into teaching mathematics. However, despite these numbers, the results reveal that males have a favourable attitude toward learning mathematics and have a higher chance of choosing and pursuing teaching as a career.

In addition, gender is unrelated to the motivation of pre-service mathematics teachers. This motivation needs to be shared widely to encourage others. The result may help gender equality inside the classroom and provide equal opportunities for both genders in mathematics related works in our country. Pre -service teachers expressed that after they began to understand the gender differences in terms of attitudes, aspirations and motivations, their environment became challenging and focused on learning. It is important for teacher education programs to understand that in order for teachers to be effective, they must possess the attitudes, aspirations, and motivations to promote academic success.

\section{References}

Ahmad, A., \& Duskri, M. (2018, September). Gender differences of mathematical critical thinking skills of secondary school students. In Journal of Physics: Conference Series (Vol. 1088, No. 1, p. 012054). IOP Publishing.

Ali, N., et. al. (2016)."A study on Attitude towards Mathematics of Secondary Students in the District of Burdwan. Retrieved from https://www.researchgate.net/publication/308966072 
Arigbabu, A. A., \& Mji, A. N. D. I. L. E. (2004). Brief Report: Is Gender a Factor in Mathematics Performance Among Nigerian Preservice Teachers?. Sex Roles, 51(11-12), 749-753. https://doi.org/10.1007/s11199-004-0724-Z

Asimeng-Boahene, L. (2006). Gender Inequity in Science and Mathematics Education in Africa: The Causes, Consequences, and Solutions. Education, 126(4).

Awang, H., \& Ismail, N. A. (2006). Gender differences in mathematics learning in Malaysia. Mlaysia: University of Malaya. Retrieved from https://www.researchgate.net/publication/268390962

Azman, N. (2013). Choosing teaching as a career: Perspectives of male and female Malaysian student teachers in training. European Journal of Teacher Education, 36(1), 113-130. https://doi.org/10.1080/02619768.2012.678483

Bagheri, F., \& Ghanizadeh, A. (2016). Critical thinking and gender differences in academic self-regulation in higher education. Journal of Applied Linguistics and Language Research, 3(3), $133-145$. http://jallr.com/index.php/JALLR/article/view/304

Bosire, J., Mondoh, H., \& Barmao, A. (2008). Effect of streamlining by gender on student achievement in mathematics in secondary schools in Kenya. South African Journal of Education, 28(4), 595-608.

Cheryan, S., Siy, J. O., Vichayapai, M., Drury, B. J., \& Kim, S. (2011). Do female and male role models who embody STEM stereotypes hinder women's anticipated success in STEM?. Social Psychological and Personality Science, 2(6), 656-664. https: // doi.org/10.1177/1948550611405218.

Coogan, P. A., \& Chen, C. P. (2007). Career development and counselling for women: Connecting theories to practice. Counselling Psychology Quarterly, 20(2), 191-204.http://dx.doi.org/10.1080/09515070701391171

Johnson, S. (1996). The Contribution of Large- Scale Assessment Programmes to Research on Gender Differences. Educational Research and Evaluation, 2(1), 25-49.

Khaleel, M. (2017). "Female students are more likely to get higher grades than male students". International Journal of Scientific and Research Publication, Volume 7, Issue 3. Retrieved from http://www.ijsrp.org/researchpaper-0317/ijsrp-p6357.pdf

Kniveton, B. H. (2004). The influences and motivations on which students base their choice of career. Research in Education, 72(1), 47-59. https://doi.org/10.7227/RIE.72.4

Manuel, J., \& Hughes, J. (2006). 'It has always been my dream': Exploring pre-service teachers' motivations for choosing to teach. Teacher Development, 10(1), 5-24. https://doi.org/10.1080/13664530600587311

Nicolaidou, M., \& Philippou, G. (2003). Attitudes towards mathematics, self-efficacy and achievement in problem solving. European Research in Mathematics Education III. Pisa: University of Pisa, 1-11.

Opolot-Okurut, C. (2005). Student attitudes towards mathematics in Ugandan secondary schools. African Journal of Research in Mathematics, Science and Technology Education, 9(2), 167-174. https://doi.org/10.1080/10288457.2005.10740587

Rao, N., Moely, B. E., \& Sachs, J. (2000). Motivational beliefs, study strategies, and mathematics attainment in highand low-achieving Chinese secondary school students. Contemporary Educational Psychology, 25(3), 287-316. https://doi.org/10.1006/ceps.1999.1003

Watt, H. M., \& Richardson, P. W. (2008). Motivations, perceptions, and aspirations concerning teaching as a career for different types of beginning teachers. Learning and instruction, 18(5), 408-428. https://doi.org/10.1016/j.learninstruc.2008.06.002 